\title{
ANALISIS PENGARUH CAPITAL INTENSITY, KEPEMILIKAN INSTITUSIONAL, DEBT TO ASSET RATIO (DAR) DAN RETURN ON ASSETS (ROA) TERHADAP EFFECTIVE TAX RATE (ETR) PADA PERUSAHAAN SEKTOR PROPERTI UTAMA YANG TERDAFTAR DI BEI PERIODE 2016 -2019
}

\author{
Chytia \\ Sekolah Tinggi Ilmu Ekonomi Wiyatamandala \\ chytia0102@gmail.com \\ Bayu Laksma Pradana \\ Sekolah Tinggi Ilmu Ekonomi Wiyatamandala \\ bayu@wym.ac.id
}

\begin{abstract}
The purpose of this study was to determine the effect of capital intensity, institutional ownership, debt to asset ratio (DAR), and return on assets (ROA) on the effective tax rate (ETR). This study uses secondary data in the form of financial reports that have been audited by auditors, where this data is obtained from the official website of the Indonesia Stock Exchange (idx.co.id). Testing in this study was assisted by using the SPSS 25 program by using multiple linear regression analysis hypothesis testing. The sample technique used in this research is purposive sampling method. The criteria taken by the author in this study are companies engaged in the property sector and have complete financial reports for 4 (four) years, from 2016-2019. The sample taken is 25 property companies for 4 years, which means that it has a total sample of 100 companies. From the existing sample, the classical assumption test was carried out consisting of the normality test, autocorrelation test, multicollinearity test, and heteroscedasticity test along with the regression coefficient similarity test consisting of the t test, $F$ test, and the coefficient of determination (R2) test.
\end{abstract}

Keywords: Effective Tax Rate, Capital Intensity, Institutional Ownership, Debt to Asset Ratio, Return on Assets

\begin{abstract}
ABSTRAK
Tujuan penelitian ini adalah untuk mengetahui pengaruh intensitas modal, kepemilikan institusional, debt to asset ratio (DAR), dan return on assets (ROA) terhadap effective tax rate (ETR). Penelitian ini menggunakan data sekunder berupa laporan keuangan yang telah diaudit oleh auditor, di mana data ini diperoleh dari situs resmi bursa efek indonesia (idx.co.id). Pengujian dalam penelitian ini dibantu dengan menggunakan program SPSS 25 dengan menggunakan analisis regresi linier berganda pengujian hipotesis. Teknik sampel yang digunakan dalam penelitian ini adalah metode purposive sampling. Kriteria yang diambil penulis dalam penelitian ini adalah perusahaan yang bergerak di bidang properti dan memiliki laporan keuangan lengkap selama 4 (empat) tahun,
\end{abstract}


dari tahun 2016-2019. Sampel yang diambil sebanyak 25 perusahaan properti selama 4 tahun yang artinya mempunyai jumlah sampel sebanyak 100 perusahaan. Dari sampel yang ada dilakukan uji asumsi klasik yang terdiri dari uji normalitas, uji autokorelasi, uji multikolinieritas, dan uji heteroskedastisitas beserta uji kesamaan koefisien regresi yang terdiri dari uji $\mathrm{T}$, uji $\mathrm{F}$, dan koefisien determinasi (R2) uji.

Kata Kunci: Tarif Pajak Efektif, Intensitas Modal, Kepemilikan Institusional, Debt to Asset Ratio, Return on Assets

\section{PENDAHULUAN}

Dalam era globalisasi seperti sekarang, perekonomian memegang peranan yang sangat penting. Salah satu bidang yang mengalami kemajuan pesat adalah perusahaan di bidang pengembang properti. Berkembangnya sektor industri pengembang properti yang sangat pesat maka akan menimbulkan persaingan yang ketat di antara industri yang sejenis. Dalam menghadapi tantangan tersebut perusahaan harus mampu memenuhi permintaan masyarakat secara efektif dan efisien yaitu mampu menyediakan dan menghasilkan unit atau area properti yang berkualitas dan menarik untuk ditempati dengan harga yang bersaing. Hal ini dilakukan untuk menghasilkan laba yang optimal dengan meminimalkan perhitungan beban pajak yang ada. Penelitian ini bertujuan untuk menguji pengaruh karakteristik pada perusahaan properti yang mana

dari perusahaan seperti capital intensity terhadap effective tax rate atau tarif pajak efektif. effective tax rate atau tarif pajak efektif merupakan variabel yang lazim digunakan untuk mengukur beban pajak perusahaan. Semakin berkurangnya dalam komposisi kepemilikan manajerial dan kepemilikan institusional mengakibatkan yang mana meningkatnya kepemilikan publik yang akan berpengaruh terhadap kenaikan value atau nilai dari perusahaan tersebut. Hal ini menggambarkan semakin besarnya kepemilikan publik dalam suatu perusahaan maka akan mendorong manajemen untuk lebih transparan sehingga perusahaan lebih kearah professional dikarenakan tidak 
dikendalikan oleh kalangan tertentu untuk memenuhi kepentingan tertentu pula. Dalam iklim bisnis sekarang ini kondisi perekonomian tidak bisa diprediksi maka selain beberapa hal di atas yang harus dipersiapkan, pengembang bisnis properti tidak hanya sekedar memiliki "uang" tetapi juga harus memiliki "senjata" yang kompetitif untuk memenangkan persaingan. Dapat kita lihat bahwa banyak perusahaan pengembang properti memenangkan persaingan karena perusahaan tersebut unggul dalam master plan (Arum, 2015). Master plan adalah suatu kerangka dari rencana pembangunan secara menyeluruh dan infrastruktur di suatu kawasan atau wilayah. Dengan memiliki master plan maka para pioneer pengembang properti dapat merespon kebutuhan customer dengan lebih cepat dan dapat lebih fleksible mengatasi perubahan pasar dan kondisi perekonomian. Bagi para pelaku bisnis properti pajak penghasilan dinilai mempunyai pengaruh terhadap laba perusahaan karena pajak penghasilan tersebut dapat mengurangi jumlah laba yang diperoleh oleh perusahaan sehingga hal ini mengakibatkan para pelaku bisnis properti melakukan perencanaan pajak (tax planning). Hal ini dilakukan sebagai upaya untuk mengurangi jumlah pajak penghasilan yang harus dibayarkan (Hashemi Rodhian Hanum, 2013). Perencanaan pajak ini terdiri dari effective tax rate (ETR) yang mana dapat diartikan sebagai besarnya beban pajak yang harus dibayarkan. Selain itu pelaku usaha properti juga harus mempertimbangkan beberapa faktor yang mempengaruhi effective tax rate (ETR), antara lain capital intensity, kepemilikan institusional, debt to asset ratio (DAR), dan return on assets (ROA).

Rumusan Masalah:

1. Bagaimana pengaruh capital intensity terhadap effective tax rate (ETR) pada bisnis sektor properti?

2. Bagaimana pengaruh kepemilikan institusional terhadap effective tax rate (ETR) pada bisnis sektor properti?

3. Bagaimana pengaruh debt to asset ratio (DAR) terhadap effective tax rate (ETR) pada bisnis sektor properti? 
Analisis Pengaruh Capital Intensity, Kepemilikan Institusional, Debt To Asset Ratio (DAR) dan Return on Asset (ROA) Terhadap Effective Tax Rate (ETR) Pada Perusahaan Sektor Properti Utama Yang Terdaftar di BEI Periode 2016-2019

4. Bagaimana pengaruh return on assets (ROA) terhadap effective tax rate (ETR) pada bisnis sektor properti?

5. Bagaimana pengaruh capital intensity, kepemilikan

\section{TELAAH LITERATUR}

Pengertian effective tax rate (ETR).

Tarif pajak efektif atau lebih sering disebut dengan effective tax rate (ETR) pada dasarnya adalah sebuah persentase besaran dari tarif pajak yang akan ditanggung oleh suatu perusahaan. Adapun pajak efektif merupakan tarif pajak yang sesungguhnya berlaku atas penghasilan wajib pajak atau pajak yang wajib dibayarkan oleh wajib pajak dan pajak efisien didefinisikan sebagai perhitungan alokasi penghasilan pajak yang dipakai dalam menutupi biaya pemungutan pajak yang terkait. Tarif pajak efektif atau effective tax rate (ETR) dari suatu perusahaan sering kali digunakan oleh para investor, para professional seperti manager ataupun manajemen suatu perusahaan dan para pemegang saham sebagai suatu alat atau instrumen untuk membuat kesimpulan tentang institusional, debt to asset ratio (DAR), dan return on assets (ROA) secara bersama-sama terhadap effective tax rate (ETR) pada bisnis sektor properti?

bagaimana sistem pajak dari suatu perusahaan. Effective tax rate (ETR)

adalah tingkat pajak efektif dari suatu perusahaan yang dapat dihitung dari beban pajak penghasilan atau beban pajak masa kini dan masa tangguhan yang kemudian dibagi dengan laba sebelum pajak (Wulandari Agustiningsih, 2016). (Price Waterhouse Coopers, 2014) merumuskan tarif pajak efektif atau effective tax rate (ETR) sebagai pajak penghasilan yang terhutang dibagi dengan laba dari perusahaan sebelum pajak penghasilan. Tarif pajak efektif sebagai rasio (persentase) merupakan pajak yang dibayarkan perusahaan berdasarkan total laba sebelum pajak penghasilan akuntansi atau komersial sehingga dapat diketahui seberapa besar persentase perubahaan-perubahaan dalam membayar pajak yang 
sebenarnya terhadap laba komersial yang diperoleh oleh perusahaan. Rumus untuk menghitung effective tax rate (ETR) atau tarif pajak efektif menurut (Hidayanti \& Laksito, 2013) adalah sebagai berikut:

\section{Effective Tax Rate $(\mathrm{ETR})=\frac{\text { Total } \operatorname{Tax} \text { Expanse }}{\text { Pretax }} \times 100 \%$}

Pengertian Modal

Menurut (Bambang Riyanto, 2010) modal diasumsikan sebagai dana yang digunakan untuk membiayai aktiva perusahaan. Menurut (Munawir, 2015) modal adalah hak atau bagian yang dimiliki oleh pemilik perusahaan yang ditunjukkan dalam pos modal (modal saham), laba ditahan, atau kelebihan nilai aktiva yang dimiliki oleh perusahaan terhadap seluruh hutang-hutangnya. Dari berbagai para ahli yang kemukakan di atas, maka dapat disimpulkan bahwa modal dipandang sebagai uang pokok, atau dapat dikatakan sebagai uang yang dipakai sebagai induk untuk berniaga, melepas uang dan sebagainya.

\section{Jenis-Jenis Modal}

Menurut (Bambang Riyanto, 2010) jenis-jenis modal terdiri dari:

1. Modal Asing/Hutang Modal Asing adalah modal yang berasal dari luar perusahaan yang sifatnya sementara di dalam perusahaan. Yang bersangkutan modal tersebut merupakan hutang yang harus dibayar kembali pada saatnya. Modal asing sering dibagi dalam 3 (tiga) golongan, yaitu:

a) Modal asing atau hutang jangka pendek (short-term debt) adalah hutang yang jangka waktunya tergolong pendek biasanya kurang dari 1 (satu) tahun.

b) Modal asing atau hutang jangka menengah (intermediate term debt) adalah hutang yang jangka waktunya biasanya diantara 1-10 tahun.

c) Modal asing atau hutang jangka panjang (long term debt) adalah hutang yang berjangka waktu lebih dari 10 tahun.

\section{Modal Sendiri}


Modal sendiri adalah modal yang berasal dari pemilik atau owner perusahaan dan yang tertanam dalam perusahaan untuk jangka waktu tertentu. Modal sendiri dibagi menjadi dua macam, diantaranya:

a. Modal sendiri yang asalnya dari sumber internal adalah berbentuk keuntungan yang dihasilkan oleh perusahaan.

b. Modal sendiri yang asalnya dari sumber eksternal adalah modal yang asalnya dari pemilik atau owner perusahaan.

\section{Pengertian Capital Intensity}

Capital intensity merupakan rasio aktivitas investasi yang dilakukan perusahaan yang dikaitkan dengan investasi dalam bentuk asset tetap. Satuan variabel capital intensity adalah persentase. Rasio dari capital intensity dapat digunakan untuk menunjukkan tingkat efisiensi perusahaan dalam menggunakan asetnya untuk menghasilkan penjualan. Semakin besar capital intensity berarti semakin efisien perusahaan tersebut dalam menggunakan modal yang ditanam. Semakin efisien berarti dalam mendapatkan atau memperoleh laba akan semakin besar, artinya beban pajak penghasilan semakin besar tentunya akan menaikkan nilai effective tax rate (ETR) demikian sebaliknya semakin rendah capital intensity berarti perusahaan kurang efisien dalam menggunakan modal yang ditanam. Menurut $(\mathrm{H} \quad \&$ Daljono, 2013) rasio capital intensity ini menunjukkan tingkat efisiensi penggunaan seluruh aktiva perusahaan di dalam menghasilkan volume penjualan tertentu. Semakin tinggi rasio capital intensity berarti semakin efisien penggunaan keseluruhan aktiva di dalam menghasilkan penjualan. Menurut (Sabli, N., 2012) menjelaskan bahwa perusahaan yang memiliki asset tetap (fixed asset) yang tinggi maka akan cenderung melakukan perencanaan pajak (tax planning). Hal ini akan mempengaruhi nilai dari effective tax rate (ETR). Pengaruh yang ditimbulkan adalah nilai dari effective tax rate (ETR) menjadi rendah. 
Capital Intensity $=\frac{\text { Total Asset Tetap Bersih }}{\text { Total Asset }} \times 100 \%$

Pengertian Kepemilikan Institusional

Menurut (Jensen, M., C., 1976) berpendapat bahwa kepemilikan institusional memiliki peranan yang sangat penting dalam melakukan minimalisasi konflik keagenan yang terjadi antara manajer dengan pemegang saham. Keberadaan dari investor institusional dianggap mampu menjadi mekanisme monitoring yang efektif dalam setiap keputusan yang diambil oleh setiap manager. Hal ini disebabkan investor kepemilikan institusional terlibat dalam pengambilan keputusan yang strategis hingga tidak mudah untuk percaya terhadap tindakan manipulasi laba. Kepemilikan institusional memiliki arti penting dalam kegiatan memonitor manajeman karena dengan adanya kepemilikan oleh institusional maka secara tidak langsung akan meningkatkan pengawasan yang lebih optimal. Monitoring tersebut tentunya agar menjamin kemakmuran bagi pemegang saham, pengaruh kepemilikan institusional sebagai agen pengawas ditekan melalui investasi mereka yang cukup besar dalam pasar modal. Kepemilikan institusional memiliki kelebihan-kelebihan diantaranya:

1. Memiliki profesionalisme dalam menganalisis informasi hingga dapat menguji keandalan informasi.

2. Memiliki motivasi yang kuat untuk melaksanakan dalam pengawasan yang lebih ketat atas aktivitas yang terjadi di dalam perusahaan. Menurut (Citra Lestari Putri \& Maya Febrianty Lautania, 2016) kepemilikan institusional adalah jumlah saham perusahaan yang dimiliki oleh pihak dari institusi maupun lembaga yang berbentuk seperti perusahaan investasi maupun perusahaan asuransi, bank, atau perusahaan swasta lainnya. Kepemilikan institusional membuat para pemegang saham memiliki kemampuan untuk melakukan pengawasan kinerja manajemen secara optimal dengan melakukan 
Analisis Pengaruh Capital Intensity, Kepemilikan Institusional, Debt To Asset Ratio (DAR) dan Return on Asset (ROA) Terhadap Effective Tax Rate (ETR) Pada Perusahaan Sektor Properti Utama Yang Terdaftar di BEI Periode 2016-2019

$\begin{array}{lr}\text { monitoring } & \text { setiap } \\ \text { pengambilan keputusan yang } & \text { dari rihak } \\ \text { diambil } & \text { dari } \\ \text { manajemen } & \text { selaku pengelola } \\ \text { perusahaan. } & \text { Semakin tinggi } \\ \text { nilai } & \text { kepemilikan }\end{array}$
institusional maka akan semakin banyak laba yang akan dibagikan, hal ini akan mengurangi nilai effective tax rate (ETR).

Kepemilikan Institusional $=\frac{\text { Jumlah Saham } \text { Institusional }}{\text { Jumlah Saham Beredar }} \boldsymbol{x} 100 \%$

Pengertian Debt to Asset Ratio (DAR)

Menurut (Munawir, 2015) debt to asset ratio (DAR) adalah rasio antara total hutang dengan aktiva. Rasio ini banyak digunakan untuk mengukur seberapa besar jumlah aktiva perusahaan yang dibiayai dengan total hutang sehingga semakin tinggi rasio ini artinya semakin besar jumlah modal pinjaman yang digunakan untuk investasi pada aktiva guna menghasilkan keuntungan bagi perusahaan. Debt to asset ratio (DAR) termasuk dari bagian rasio solvabilitas. Rasio solvabilitas adalah rasio yang digunakan untuk mengukur sejauh mana aktiva perusahaan dibiayai dari kewajiban atau hutang. Bisa digambarkan secara sederhana rasio solvabilitas menunjukkan kemampuan dari perusahaan untuk membayarkan seluruh kewajiban atau hutang yang dimilikinya untuk memenuhi kewajiban hutang jangka panjang atau utang yang jangka waktunya lebih dari satu tahun pada kondisi perusahaan mengalami likuidasi. Apabila perusahaan yang mengalami likuidasi tersebut mampu melunasi atau membayar seluruh kewajiban atau hutangnya tanpa mengalami defisit, bisa dikatakan kinerja dari perusahaan tersebut tergolong baik sehingga para investor akan percaya untuk menanamkan modalnya terhadap perusahaan tersebut. Hal demikian akan sangat berpengaruh terhadap besarnya harga saham perusahaan tersebut. Debt to asset ratio (DAR) dapat dihitung dengan rumus: 
Debt to Asset Ratio $(\mathrm{DAR})=\frac{\text { Total Debt }}{\text { Total Assets }} \times 100 \%$

Pengertian Return on Asset (ROA)

Rasio ini mengukur seberapa jauh kemampuan dari perusahaan menghasilkan laba dari aktiva yang dipergunakan dalam perusahaan. Rasio ini digunakan untuk suatu ukuran tentang efektivitas dalam suatu manajemen untuk pengelolaan investasi. Return on assets (ROA) dalam penelitian ini indikator effective tax rate (ETR) yang digunakan oleh penulis adalah return on asset (ROA) karena return on asset (ROA) paling berkaitan dengan efisiensi dan efektivitas suatu perusahaan dalam menghasilkan laba, sehingga dengan kata lain bahwa return on asset (ROA) merupakan indikator yang digunakan untuk mengukur seberapa besar keuntungan perusahaan dibandingkan dengan keseluruhan aset yang dimiliki. Semakin besar berpengaruh terhadap effective tax rate (ETR) karena pada rumus return on assets (ROA) terdapat laba bersih dan rata-rata total asset, hal ini yang mempungaruhi perhitungan variabel dependennya. return on assets (ROA) nilai dari return on asset (ROA) semakin besar pula tingkat dari keuntungan yang dapat dicapai perusahaan dan semakin baik pula kondisi dan posisi perusahaan dalam segi pemakaian serta penggunaan asset. Nilai return on asset (ROA) yang besar akan menunjukkan kinerja dari suatu perusahaan yang semakin baik dikarenakan tingkat pengembalian investasi yang juga semakin besar. Angka return on asset (ROA) bisa dikatakan baik apabila memiliki nilai lebih besar dari 2\%. Return on Asset (ROA) pada dasarnya merupakan sebuah rasio yang menunjukkan antara imbal hasil atau dapat dikatakan return terhadap jumlah aktiva yang digunakan oleh suatu perusahaan. Pendekatan return on asset (ROA) menggambarkan bahwa besarnya laba yang diperoleh oleh perusahaan dengan menggunakan total asset yang dimilikinya. Jadi semakin tinggi rasio ini tentunya semakin baik performa perusahaan dalam menggunakan asset untuk memperoleh laba bersih. 


\section{METODOLOGI PENELITIAN}

Dalam penelitian ini, objek penelitiannya adalah perusahaan sektor properti utama yang terdaftar di Bursa Efek Indonesia (BEI). Jenis penelitian ini menggunakan kuantitatif, dengan metode pendekatan asosiatif dan deskriptif, data yang dikumpulkan dalam bentuk angka dari data sekunder yang diperoleh dari laporan keuangan perusahaan sektor properti utama yang terdaftar di BEI periode 2016 - 2019. Untuk sumber data penelitian menggunakan data sekunder yang mana data tersebut diperoleh bukan langsung dari sumbernya melainkan diperoleh dari laporan keuangan perusahaan sektor properti utama pada periode 2016 2019 yang berasal dari IDX Statistics (https://www.idx.co.id/). Teknik analisis data yang digunakan untuk memecahkan permasalahan dalam penelitian ini adalah analisis regresi linear berganda dengan bantuan program SPSS. Analisis regresi linear berganda adalah hubungan secara linear antara dua atau lebih variabel independen $\left(\mathrm{X}_{1}, \mathrm{X}_{2}, \mathrm{Xn}\right)$ dengan variabel dependen (Y). Menurut (Sugiyono, 2014) analisis regresi linear berganda bermaksud meramalkan bagaimana keadaan (naik turunnya) variabel dependen (terikat), bila dua atau lebih variabel independen sebagai faktor bebas dimanipulasi.

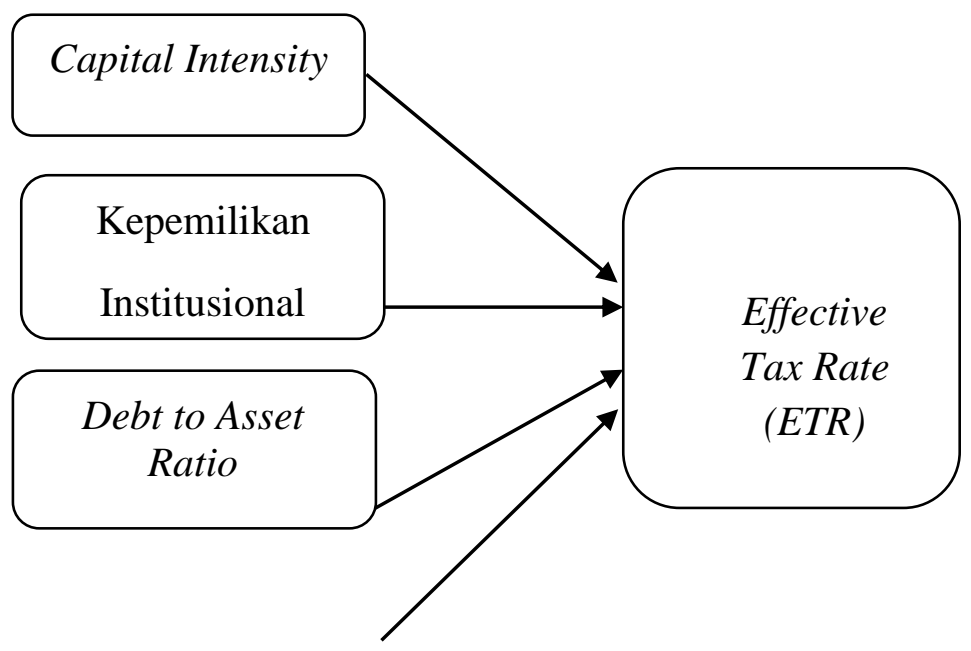


Hipotesi $\begin{gathered}\text { Return on Assets } \\ (\text { ROA })\end{gathered}$

$\mathrm{T}_{1}$ : Terdapat pengaruh negatif tidak signifikan capital intensity terhadap effective tax rate (ETR) secara parsial.

$\mathrm{T}_{2}$ : Terdapat pengaruh negatif tidak signifikan kepemilikan institusional terhadap effective tax rate (ETR) secara parsial.

$\mathrm{T}_{3}$ : Terdapat pengaruh negatif tidak signifikan debt to asset ratio (DAR) terhadap effective tax rate (ETR) secara parsial.

\section{HASIL DAN PEMBAHASAN}

Uji Normalitas

Untuk mengetahui apakah data berdistribusi normal dalam model regresi maka digunakan uji normalitas dan juga data plotting. Model regresi yang baik memiliki distribusi normal. Pada tabel dibawah ini, nilai signifikansi yang dihasilkan adalah 0.086 di mana nilai
T4: Terdapat pengaruh signifikan positif return on assets (ROA) terhadap effective tax rate (ETR) secara parsial. F: Terdapat pengaruh signifikan capital intensity, kepemilikan institusional, debt to asset ratio (DAR), dan return on asset (ROA) terhadap effective tax rate (ETR) secara simultan.

tersebut melebihi dari 0.05. Artinya pada model regresi ini data berdistribusi normal. Kemudian titiktitik pada data plotting terlihat mengikuti garis diagonal, maka tidak ada penyimpangan dan data tersebut berdistribusi dengan normal. 
Tabel 1. Hasil Uji Normalitas

\begin{tabular}{ccl}
\hline \multicolumn{4}{c}{ One-Sample Kolmogorov-Smirnov Test } \\
\multicolumn{4}{c}{$N$} & 92 \\
Normal Parameters $^{a, b}$ & Mean & .0000000 \\
& Std. & 1.48721881 \\
& Deviation \\
Most Extreme & Absolute & .086 \\
Differences & Positive & .042 \\
\multicolumn{4}{c}{ Negative } & -.086 \\
Test Statistic & .086 \\
Asymp. Sig. (2-tailed) & $.086^{\mathrm{c}}$ \\
\hline
\end{tabular}

a. Test distribution is Normal.

b. Calculated from data. Lilliefors Significance Correction

Gambar 2 Plotting

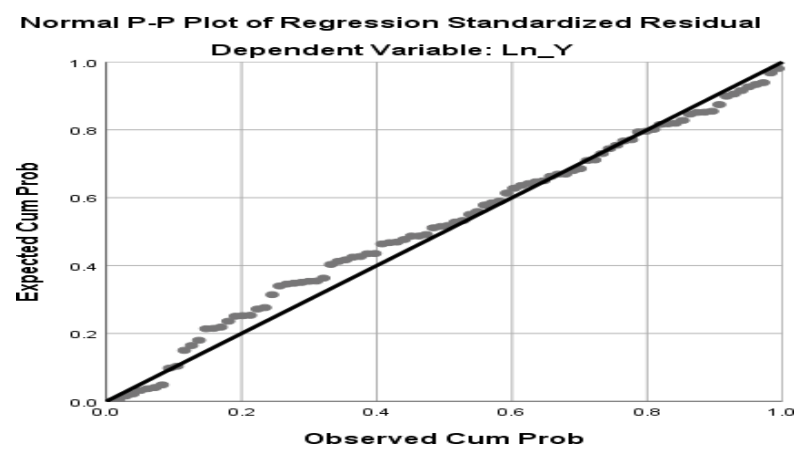

Uji Multikolinearitas

Uji multikolinearitas digunakan untuk menguji adanya korelasi antar variabel independen. Model regresi yang baik adalah tidak ada gejala multikolinearitas. Nilai tolerance > 0.10 dan nilai VIF $<10.00$ maka tidak terjadi multikolinearitas. Di bawah ini merupakan tabel hasil uji multikolinearitas: 
Tabel 2 Hasil Uji Multikolinearitas

\begin{tabular}{|c|c|c|c|c|c|c|}
\hline & $\begin{array}{r}\text { Unstar } \\
\text { Coef. }\end{array}$ & $\begin{array}{l}\text { ardized } \\
\text { ients }\end{array}$ & $\begin{array}{c}\text { Standardized } \\
\text { Coefficient }\end{array}$ & & & $\begin{array}{l}\text { Collinearity } \\
\text { Statistics }\end{array}$ \\
\hline Model & $\boldsymbol{B}$ & $\begin{array}{l}\text { Std. } \\
\text { Error }\end{array}$ & Beta & $t$ & Sig. & Tolerance \\
\hline Constant) & 6.682 & 3.380 & & 1.977 & .051 & \\
\hline $\bar{L}$ Ln_X1 & -.060 & .286 & -.022 & -.209 & .835 & .8301 .205 \\
\hline Ln_X2 & -1.109 & .725 & -.176 & -1.529 & .130 & .6901 .449 \\
\hline Ln_X3 & .189 & .261 & .084 & .725 & .470 & .6801 .470 \\
\hline Ln_X4 & -.680 & .215 & -.323 & -3.167 & .002 & .8771 .140 \\
\hline
\end{tabular}

Dependent Variable: Ln_Y

Berdasarkan tabel tersebut semua variabel memiliki nilai tolerance > 0.10 dan nilai VIF $<10.00$. Hal ini menunjukan model regresi tidak ada gejala multikolinearitas.

Uji Heterokedastisitas

Uji heteroskedastisitas digunakan untuk menguji adanya ketidaksamaan varian dari residual satu pengamatan ke pengamatan lain.
Model regresi yang baik apabila tidak ada gejala heteroskedastisitas. Dalam penelitian ini uji heteroskedastisitas dengan cara uji glejser dan melihat melihat pola titiktitik pada scatterplot regresi. Heteroskedastisitas tidak terjadi apabila nilai signifikan $>0.05$ pada setiap variabel independen. Berikut adalah tabel uji heterokedastisitas dengan uji glejser: 


\begin{tabular}{rrrrrrr} 
Model & & \multicolumn{1}{c}{$\begin{array}{c}\text { Unstandarized } \\
\text { Coefficients } \\
\text { Std. Error }\end{array}$} & $\begin{array}{c}\text { Standardized } \\
\text { Coefficients } \\
\text { Beta }\end{array}$ & \multicolumn{1}{c}{ Sig. } \\
(Constant) & 7.470 & 7.117 & & 1.050 & .297 \\
Ln_X1 & .014 & .043 & .038 & .332 & .741 \\
Ln_X2 & -.083 & .066 & -.148 & -1.254 & .213 \\
Ln_X3 & 8.357 & 5.105 & .197 & 1.637 & .105 \\
Ln_X4 & -.226 & .243 & -.100 & -.930 & .354 \\
\hline
\end{tabular}

a. Dependent Variable: Effective Tax Rate

Tabel diatas menunjukan nilai melebar, kemudian menyempit) pada signifikan seluruh variabel lebih gambar scatterplot, serta titik - titik besar dari 0.05, hal tersebut menyebar di atas dan di bawah angka menunjukan bahwa data penelitian 0 pada sumbu Y. Di bawah ini tidak terjadi gejala adalah gambar scatterplot hasil heteroskedastisitas. Kemudian tidak penelitian: ada pola yang jelas (bergelombang,

\section{Tabel 4. Hasil Scatterplot}

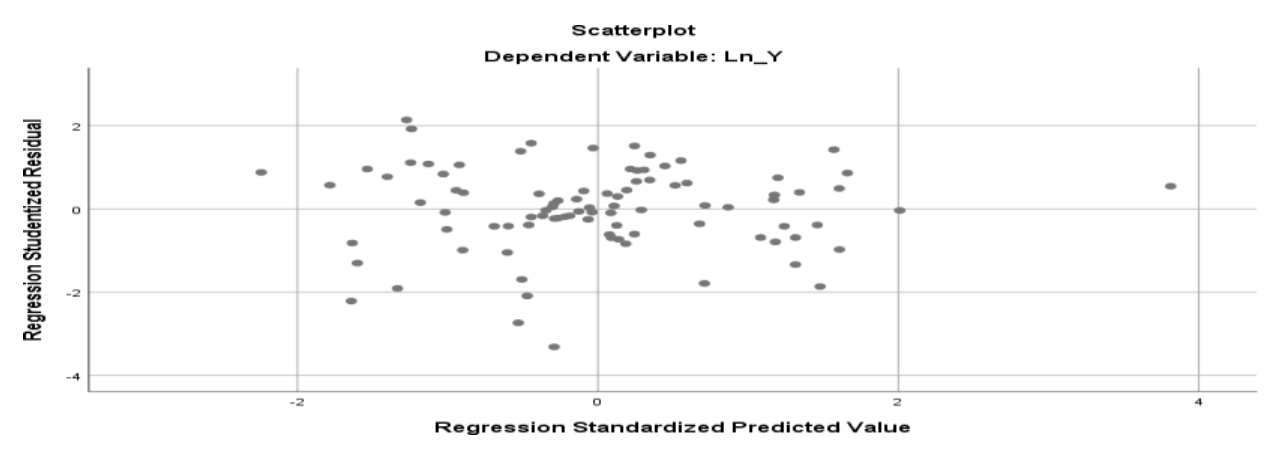

Pada gambar tersebut tidak ada pola yang jelas dan titik - titik menyebar di atas dan di bawah angka 0 pada sumbu Y, artinya model regresi tidak ada gejala heteroskedastisitas.

Uji Autokorelasi
Uji autokorelasi digunakan untuk mengetahui adanya korelasi antara korelasi residual pada periode $\mathrm{t}$ dengan periode t-1 (sebelumnya). Model regresi yang baik adalah tidak adanya gejala autokorelasi. Hasil uji 
autokorelasi tidak ada gejala penelitian dengan signifikansi 0.05 . autokorelasi jika nilai Durbin Pada penelitian ini nilai dU sebesar Watson terletak antara du sampai 1.7582. Hasil uji autokorelasi bisa dengan (4- du). Nilai du dicari pada dilihat pada tabel berikut distribusi nilai tabel Durbin Watson berdasarkan jumlah variabel independen dan banyaknya sampel

Tabel 4 Hasil Uji Autokorelasi Durbin-Watson

$$
\text { Model Summary }{ }^{b}
$$

\begin{tabular}{|c|c|c|c|c|c|}
\hline Model & $\boldsymbol{R}$ & $\begin{array}{c}R \\
\text { Square }\end{array}$ & $\begin{array}{c}\text { Adjusted } R \\
\text { Square }\end{array}$ & $\begin{array}{c}\text { Std. Error } \\
\text { of the } \\
\text { Estimate }\end{array}$ & $\begin{array}{l}\text { Durbin- } \\
\text { Watson }\end{array}$ \\
\hline & $.272^{\mathrm{a}}$ & .074 & .035 & 8.20201 & 2.128 \\
\hline
\end{tabular}

a) Predictors: (Constant), Lag_X4,Lag_X1, Lag_X2,Lag_X3

b) Dependent Variable: Lag_Y

Berdasarkan tabel tersebut, nilai Durbin Watson sebesar 2.128 dan nilai (4-dU) sebesar 2.2418, sehingga dU (1.7582) < Durbin Watson $(2.128)<4-\mathrm{dU}$ (2.2418), artinya model regresi ini tidak terdapat gejala autokorelasi.

Hasil Uji t (secara parsial)

Nilai Signifikan $<0.05$ artinya variabel independen secara parsial berpengaruh terhadap variabel dependen. Dalam penelitian ini hipotesis uji t (secara parsial) sebagai berikut:

$\mathrm{H} 0: \beta \mathrm{i}=0$

$\mathrm{H \alpha}: \beta \mathrm{i} \neq 0$

Di mana $\beta$ i merupakan koefisien variabel independen ke-i sebagai nilai parameter hipotesis. Nilai $\beta$ dianggap nol yang artinya tidak ada pengaruh variabel independen ke-i terhadap variabel dependen. 
Tabel 5 Hasil Uji Secara Parsial (Uji t)

\begin{tabular}{|c|c|c|c|c|c|c|}
\hline \multirow[b]{2}{*}{ Model } & & \multicolumn{2}{|c|}{$\begin{array}{c}\text { Unstandardized } \\
\text { Coefficients }\end{array}$} & \multirow{2}{*}{$\begin{array}{c}\text { Standardized } \\
\text { Coefficients } \\
\text { Beta }\end{array}$} & \multirow[b]{2}{*}{$T$} & \multirow[b]{2}{*}{ Sig. } \\
\hline & & B & Std. Error & & & \\
\hline 1 & (Constant) & 6.682 & 3.380 & & 1.977 & .051 \\
\hline & Ln_X1 & -.060 & .286 & -.022 & -.209 & .835 \\
\hline & Ln_X2 & -1.109 & .725 & -.176 & -1.529 & .130 \\
\hline & Ln_X3 & .189 & .261 & .084 & .725 & .470 \\
\hline & Ln_X4 & -.680 & .215 & -.323 & -3.167 & .002 \\
\hline
\end{tabular}

a. Dependent Variable: Ln_Y

Hasil analisis sebagai berikut:

1. Capital intensity variabel independen secara Nilai Signifikan $>0.05$ artinya parsial tidak berpengaruh variabel independen secara terhadap variabel dependen. Pada Parsial tidak berpengaruh tabel 6 nilai signifikansi debt asset ratio terhadap variabel dependen. Pada debt asset ratio (DAR) adalah 0.470 tabel 6 nilai signifikansi capital intensity lebih besar dari 0.05, maka debt intensity adalah 0.835 lebih besar debt to asset ratio (DAR) tidak dari 0.05, maka capital intensity berpengaruh signifikan terhadap tidak berpengaruh signifikan

effective tax rate (ETR).

2. Kepemilikan Institusional

Kepemilikan Institusional

nilai signifikan $>0.05$ artinya

variabel independen secara

parsial tidak berpengaruh

terhadap variabel dependen.

Pada tabel nilai signifikansi

kepemilikan institusional

adalah 0.130 lebih besar dari

0.05, maka kepemilikan

institusional tidak

berpengaruh signifikan

terhadap effective tax rate

(ETR).

3. Debt to Asset Ratio (DAR)

Nilai Signifikan $>0.05$

artinya variabel independen

secara parsial tidak

berpengaruh terhadap 
variabel dependen. Pada tabel

nilai signifikansi debt to asset ratio (DAR) adalah 0.470 lebih besar dari 0.05, maka debt to asset ratio (DAR) tidak berpengaruh signifikan terhadap effective tax rate (ETR).

4. Return on assets (ROA)
Nilai Signifikan $<0.05$ artinya variabel independen secara parsial berpengaruh terhadap variabel dependen. Pada tabel 6 nilai signifikansi return on assets 0.002 lebih kecil dari 0.05 , maka return on assets (ROA) berpengaruh signifikan terhadap effective tax rate (ETR).

dependen. Dalam penelitian ini hipotesis uji F (secara simultan) sebagai berikut:

variabel independen secara simultan berpengaruh terhadap variabel

\begin{tabular}{rrrrrr} 
& \multicolumn{7}{c}{$\begin{array}{c}\text { Unstandardized } \\
\text { Coefficients }\end{array}$} & $\begin{array}{c}\text { Standardized } \\
\text { Coefficients } \\
\text { Model }\end{array}$ & \multicolumn{1}{c}{ B } & Std. Error & Beta & \multicolumn{1}{c}{ T } & \multicolumn{1}{c}{ Sig. } \\
(Constant) & 6.682 & 3.380 & & 1.977 & .051 \\
Ln_X1 & -.060 & .286 & -.022 & -.209 & .835 \\
Ln_X2 & -1.109 & .725 & -.176 & -1.529 & .130 \\
\hline
\end{tabular}

$\mathrm{H} 0: \beta 1=\beta 2=\beta 3=0$

Hasil uji $F$ dapat dilihat pada tabel

$\mathrm{H \alpha}$ : minimal ada satu koefisien dibawah ini:

regresi tidak sama dengan nol

Tabel 6. Hasil Uji Secara Simultan (Uji F)

\begin{tabular}{|c|c|c|c|c|c|c|}
\hline \multicolumn{2}{|c|}{ Model } & $\begin{array}{l}\text { Sum of } \\
\text { Squares }\end{array}$ & $d f$ & Mean Square & \multirow{2}{*}{$\begin{array}{c}F \\
5.606\end{array}$} & \multirow{2}{*}{$\begin{array}{l}\text { Sig. } \\
.000^{b}\end{array}$} \\
\hline 1 & Regression & 51.877 & 4 & 12.969 & & \\
\hline & Residual & 201.276 & 87 & 2.314 & & \\
\hline & Total & 253.153 & 91 & & & \\
\hline
\end{tabular}

a. Dependent Variable: Ln_Y 


\section{b. Predictors: (Constant), Ln_X4, Ln_X1, Ln_X2, Ln_X3}

Dari hasil analisis regresi dapat diketahui bahwa secara bersamasama atau simultan variabel independen memiliki pengaruh terhadap variabel dependen karena nilai signifikan uji F 0.000 lebih kecil dari nilai signifikan 0.05 . Melihat hasil tersebut maka capital intensity, kepemilikan institusional, debt to asset ratio (DAR), dan return on assets (ROA) secara simultan berpengaruh terhadap effcetive tax rate (ETR).
Uji Koefisien Determinasi

Tujuan dari uji koefisien determinasi $\left(\mathrm{R}_{2}\right)$ adalah untuk mengukur seberapa jauh kemampuan model dalam menerangkan variabel dependennya. Nilai $R_{2} \quad$ yang mendekati satu berarti variabel independennya memberikan hampir semua informasi yang dibutuhkan untuk memprediksi variasi variabel dependen. Di bawah ini merupakan hasil analisis koefisien determinasi:

Tabel 7 Hasil Uji Koefisien Determinasi

\begin{tabular}{lc|c|c|c} 
Model & $\boldsymbol{R}$ & $\boldsymbol{R}$ Square & $\begin{array}{c}\text { Adjusted } \boldsymbol{R} \\
\text { Square }\end{array}$ & $\begin{array}{c}\text { Std. Error } \\
\text { of the } \\
\text { Estimate }\end{array}$ \\
\hline $1 \quad .453^{\mathrm{a}}$ & .205 & .168 & 1.52102 \\
\hline \multicolumn{2}{l}{$\begin{array}{l}\text { a. Predictors: (Constant), Ln_X4, Ln_X1, Ln_X2, Ln_X3 } \\
\text { b. Dependent Variable: Ln_Y }\end{array}$}
\end{tabular}

Berdasarkan tabel 7 terlihat bahwa hasil perhitungan atau analisis diperoleh nilai adjusted $\mathrm{R}_{2}$ sebesar 0.168 atau $16.8 \%$. Hasil ini menunjukan bahwa besarnya pengaruh variabel independen yaitu capital intensity, kepemilikan institusional, debt to asset ratio (DAR), dan return on asset (ROA) terhadap variabel dependen yaitu effective tax rate (ETR) sebesar $16.8 \%$ dan sisanya $83.2 \%$ dipengaruhi oleh faktor - faktor lain yang tidak dimasukan dalam model regresi penelitian ini. Dari hasil penelitian tersebut maka diperoleh hasil analisa:

$\mathrm{T}_{1}$ : Tidak diterima. Dalam penelitian ini capital intensity tidak terbukti berpengaruh signifikan terhadap 
effective tax rate (ETR) karena para investor cenderung menggunakan faktor-faktor lainnya dalam mengambil keputusan berinvestasi serta perusahaan kurang efisien dalam menggunakan modal yang ditanam.

$\mathrm{T}_{2}$ : Tidak diterima. Dalam penelitian ini kepemilikan institusional tidak terbukti berpengaruh signifikan terhadap effective tax rate (ETR) dikarenakan jika kepemilikan investor tinggi dan perusahaan melakukan pembagian deviden dalam jumlah yang besar hal ini akan menimbulkan pembayaran pajak perusahaan dalam nominal yang rendah.

$\mathrm{T}_{3}$ : Tidak diterima. Pada penelitian ini debt to asset ratio (DAR) tidak terbukti berpengaruh signifikan

\section{SIMPULAN DAN SARAN}

Berdasarkan hasil analisis dan pembahasan yang telah diuraikan di bab sebelumnya, dapat disimpukan terdapat pengaruh negatif dan signifikan return on assets (ROA) terhadap effective tax rate (ETR) secara parsial terhadap perusahaan sektor properti utama yang terdaftar di Bursa Efek Indonesia periode terhadap effective tax rate (ETR) dikarenakan jika perusahaan memiliki utang atau solvabilitas yang tinggi hal ini tidak diperlukan pembayaran pajak hanya cukup melakukan pelaporan saja. Biaya bunga dapat mengurangi pendapatan perusahaan sebelum pajak.

$\mathrm{T}_{4}$ : Diterima. Pada penelitian ini return on assets (ROA) berpengaruh signifikan negatif karena semakin tinggi nilai ROA maka akan semakin besar pembayaran pajak dan akan berdampak pada kenaikan nilai effective tax rate (ETR). Perusahaan yang memiliki tingkat ROA yang tinggi akan menarik perhatian lebih dari stakeholder.

2016-2019 dan terdapat pengaruh signifikan capital intensity, kepemilikan institusional, debt to asset ratio (DAR), dan return on asset (ROA) secara parsial terhadap perusahaan sektor properti utama yang terdaftar di Bursa Efek Indonesia periode 2016 - 2019. Penelitian ini menggambarkan 
Analisis Pengaruh Capital Intensity, Kepemilikan Institusional, Debt To Asset Ratio (DAR) dan Return on Asset (ROA) Terhadap Effective Tax Rate (ETR) Pada Perusahaan Sektor Properti Utama Yang Terdaftar di BEI Periode 2016-2019

capital intensity, kepemilikan institusional, debt to asset ratio (DAR) yang tidak berpengaruh signifikan terhadap effective tax rate (ETR) yang disebabkan oleh banyak faktor lain di luar variabel independen yang diteliti, oleh karena itu tidak menutup kemungkinan effective tax rate (ETR) dapat dianalisis dengan menggunakan perbandingan variabel atau rasio lain.

\section{DAFTAR PUSTAKA}

Arum, N. . (2015). 5 Hal Ini Harus Diperhatikan Pebisnis Properti Baru. Bisnis.Com.

Bambang Riyanto. (2010). DasarDasar Pembelanjaan Perusahaan (4 Ed.). Yogyakarta: Bpfe.

Citra Lestari Putri \& Maya Febrianty Lautania. (2016). Pengaruh Capital Intensity Ratio, Inventory Intensity Ratio, Ownership strucutre dan Profitability Terhadap Effective Tax Rate(ETR) (Studi Pada Perusahaan manufaktur Yang terdaftar Di Bursa Efek Indonesia Tahun 2011-2014). Jurnal Ilmiah Mahasiswa Ekonomi Akuntansi, 1(1), 101119.

H, W. P. \&, \& Daljono. (2013). Pengaruh Perusahaan, Ukuran Leverage, Rasio Intensitas Modal, Dan Likuiditas Perusahaan Perusahaan, Terhadap Konservatisme (Ifrs, Studi Pada Perusahaan Yang Belum Menggunakan). Diponegoro
Periode pada penelitian ini adalah empat tahun, sangat diharapkan jika peneliti selanjutnya untuk menambah periode penelitian, menambahkan perusahaan sektor lain seperti perusahaan yang bergerak di bidang manufaktur dengan tujuan untuk memperoleh hasil yang lebih akurat mengenai pengaruh rasio keuangan effective tax rate (ETR).

Journal Of Accounting, 2(3).

Hashemi Rodhian Hanum, Z. (2013).

Pengaruh Karakteristik

Corporate Governance terhadap Effective Tax Rate(Studi Empiris Pada Bumn Yang Terdaftar Di Bei 2009-2011). Diponegoro Journal Of Accounting, 2(2), 1-10. Hidayanti, A. N., \& Laksito, H. (2013). Pengaruh Antara Kepemilikan Keluarga Dan Corporate Governance Terhadap Tindakan Pajak Agresif. Diponegoro Journal of Accounting, 2(2), 1-12.

Jensen, M., C., \& W. M. (1976). Theory Of The Firm: Managerial Behavior, Agency Cost And Ownership Structure. Journal Of Finance Economic, 3(1), 305-360.

Munawir. (2015). Analisis Laporan Keuangan. Jakarta: Liberty. Price Waterhouse Coopers. (2014). Member Firms Worldwide. Sabli, N., \& N. M. R. (2012). Tax Planning And Corporate 
Governance.

Sugiyono. (2014). Metode Penelitian

Kuantitatif Kualitatif Dan $R \& D$.

Bandung: Alfabeta.

Wulandari Agustiningsih, I. I.

(2016). Pengaruh Penerapan E-
Filling, Tingkat Pemahaman

Perpajakan Dan Kesadaran

Wajib Pajak Terhadap

Kepatuhan Wajib Pajak Di Kpp

Pratama Yogyakarta. Jurnal

Nominal, 5(2), 107-122. 